\title{
Dystonia caused by putamino-capsulo-caudate vascular lesions
}

\author{
B DEMIERRE AND P RONDOT \\ From the Service of Neurology, Hôpital Sainte Anne, Paris, France
}

SUMMARY Three cases of unilateral dystonia of vascular origin are presented and compared with those in the literature. Damage in the region of the lenticulostriate arteries accounted for ischaemic lesions of the putamino-capsulo-caudate region, the external pallidum probably also being involved. This syndrome appears if the ischaemic accident took place during childhood. The functions of each of these structures and the possible role of the anterior limb of the internal capsule are discussed.

Dystonia represents a particular group of diseases involving the motor system. Denny-Brown ${ }^{1}$ defined it as "a fixed or relatively fixed attitude in association with other extrapyramidal disorders of movement". Dystonia musculorum deformans is its major form, but the absence of specific pathology in this condition makes any physiopathological interpretation particularly difficult. ${ }^{2}$ However, besides this idiopathic, occasionally hereditary ${ }^{3}$ form of the disease, dystonic syndromes can occur in metabolic, ${ }^{4}$ anoxic, ${ }^{5}$ tumoural $^{6}$ and infectious disorders. ${ }^{7}$ Dystonia of vascular origin is particularly interesting, because the responsible lesions may be more limited than those of metabolic or anoxic origin, thus permitting speculation on the pathological-anatomic basis of this unique motor disease. Vascular dystonia usually is unilateral, and frequently, but not necessarily, follows a hemiplegia. ${ }^{18-15}$ We report three cases in which the CT scan enabled us to diagnose the obliteration of a lenticulo-striate artery, causing lesions in the putamen, to the head of the caudate nucleus and to the anterior limb of the internal capsule.

\section{Case Reports}

Case 1 A 3-year-old child without any medical, surgical or family history, had a mild head injury without loss of consciousness in $1967 ; 15$ minutes later, the parents

Address for reprint requests: Prof P Rondot, Service of Neurology, Hopital Sainte Anne, 1 rue Cabanis, 75674 Paris Cedex 14, France.

Received 6 September 1982 and in revised form 21 November 1982.

Accepted 2 December 1982. noticed that the child was crying and that she had micturated. Two days later, a right hemiparesis with dysarthria occurred, without any disorder of comprehension, in a matter of several minutes. The right hemiparesis improved over four weeks but, at the same time, dystonia appeared in right upper and lower limbs, with athetoid movements of the right hand. Anticholinergic treatment (trihexyphenidyl) aggravated the symptoms. In 1979, the patient was admitted to the neurological ward of the Centre Hospitalier Saint-Anne, where clinical examination revealed athetoid movements of the right upper limb and a dystonic posture involving mainly the upper but also the right lower limb. The dystonia became worse with voluntary movements. The right plantar response was extensor. The rest of the neurological examination was normal.

CT scan showed a hypodense lesion involving the head of the left caudate nucleus, the putamen and the anterior limb of the internal capsule (fig 1), without any visible arterio-venous malformation. A left carotid arteriogram showed dilatation of the left sylvian group of vessels, with early venous drainage and an accentuation of the small vessels of the insular region. Surface electromyogram of the flexor and extensor muscles of the right upper limb showed that, during passive movements, there was a shortening reflex as well as an exaggerated myotatic reflex in the muscles examined. Attitude fixing, stress and movement executed by other muscle groups induced bursts of long-duration activity.

Treatment for six months with baclofen and tetrazepam was without effect. Piribedil, under electromyographical control, induced a hypotonia of the right half of the body, with cessation of abnormal movements and of the muscle shortening reflex for 15 minutes. The patient was then treated with piribedil, baclofen and clonazepam, with a slight improvement of symptoms.

The patient was seen again in April 1982 and the following clinical observations were made: $O n$ walking: the right elbow was in extension, and the wrist and thumb were in hyperflexion; the hand had the attitude of a "bowl player", the fingers having a tendency to extension and abduction. 

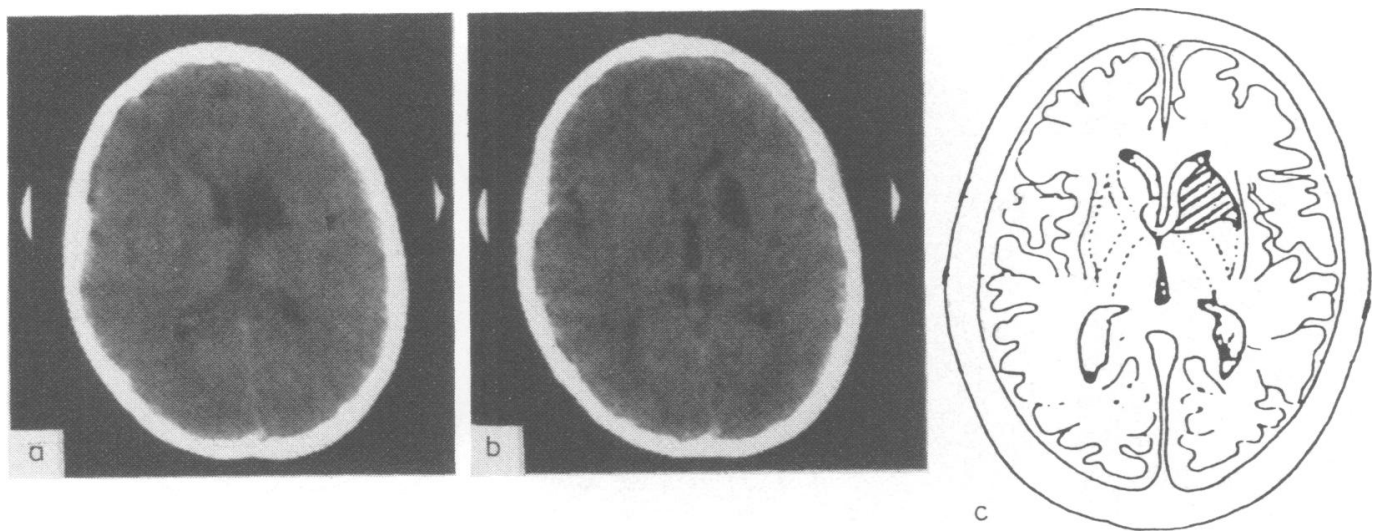

Fig 1 Case 1 CT scan without contrast: hypodensity of the left lenticulo-capsulo-caudate region.

At rest: there was a generalised hypotonia of the upper limb interrupted by marked spasms with flexion-extension movements of the elbow and wrist. There was an exaggeration of the shortening reflex of the triceps muscle. The position of the right lower limb was the opposite to that of the right upper limb with a tendency to flexion of the knee and extension of the foot, the latter setting itself in varus equinus. The choreo-athetoid movements were exaggerated with sensory stimulation, or with emotions. There was improvement of symptoms on treatment with piribedil, clonazepam and dantrolene.

Case 2 A seven-year-old, left-handed schoolgirl, without any medical, surgical or family history, had a sudden 15 minutes loss of consciousness. On waking, a left hemiplegia without speech disorder was noted. Three weeks later, there was a partial recovery of the hemiplegia, but dystonia of the left upper-limb developed with hyperflexion of the elbow and wrist. The foot was in varus equinus with hyperflexion of the toes. The family noted a postural tremor in the left upper-limb and, two years later, athetoid type movements of the left hand.

We examined this patient in 1980 and 1982: On walking: There was a tendency to hyperextension and external rotation of the left lower-limb with hyperflexion of the toes and a limp. There was hyperextension-anteduction of the elbow with a tendency to separate from the body, and hyperflexion of the wrist and hyperextension-abduction of the fingers and athetoid movements. At rest: we observed alternately hypertonia with shortening of the triceps and biceps muscles on passive movements of the elbow and ankle, followed by hypotonia. Voluntary movements were executed very slowly with creeping motions of the hand and wrist, pronounced "main creuse" with adduction of the thumb. The foot was in varus equinus with hyperflexion of the toes. Abnormal movements increased with sensory stimulation and emotion. The left plantar response was extensor and there was a facial assymetry. The rest of the neurological examination was normal.

The surface electromyogram of the deltoid, and extensor and flexor muscles of the left elbow showed tonic activity of these muscles during attitude fixing, exaggerated by performing mental arithmetic. During passive movement of the wrist, a tonic myotatic flexor response and a shortening reaction of the extensor muscles was recorded. CT scan showed a hypodensity of the right putaminocapsulo-caudate region without any visible arteriovenous malformation (fig 2). The patient refused an arteriographic examination.

We noted a mild improvement of the dystonia with an almost complete cessation of abnormal movements on treatment with benzodiazepine or dantrolene.

Case 3 A 17-year-old right-handed patient, without any medical surgical or family history developed a sudden left hemiplegia, The patient was stuporous, with a left hemiplegia and left facial hypoaesthesia. Bilateral vertebral artery murmurs were heard. The level of consciousness improved over four days, with a complete regression of the sensory disturbances and a partial regression of the motor deficit. During treatment there was one episode of a auricular fibrillation followed by ventricular premature beats. On discharge, four weeks later, there was a partial left hemiplegia but dystonic disorders had appeared. A right carotid arteriogram was normal.

CT scan showed a hypodensity with a central hyperdensity of the right lenticulo-capsulo-caudate region.

Clinical examination in 1982 showed there was on walking: extension of the left elbow as well as of the wrist with flexion of the metacarpo-phalangeal joints. The left arm had a tendency to retropulsion-abduction with elevation of the shoulders. The hand was hollow with adduction of the thumb, hyperextension-abduction of the first three fingers and athetoid movements of each of the latter. The left lower limb was held in external rotation with hyperflexion of the toes, without abnormal movements. At rest: The left half of the body was rather hypotonic with a sudden contraction and shortening of the triceps on passive extension of the elbow. The same phenomenon was noted at the left wrist and ankle. There was a left hemiparesis with an extensor plantar response. The rest of the neurological examination was normal.

Cardiological investigations showed a mitral valve prolapse, which probably was the cause of the intermittent 

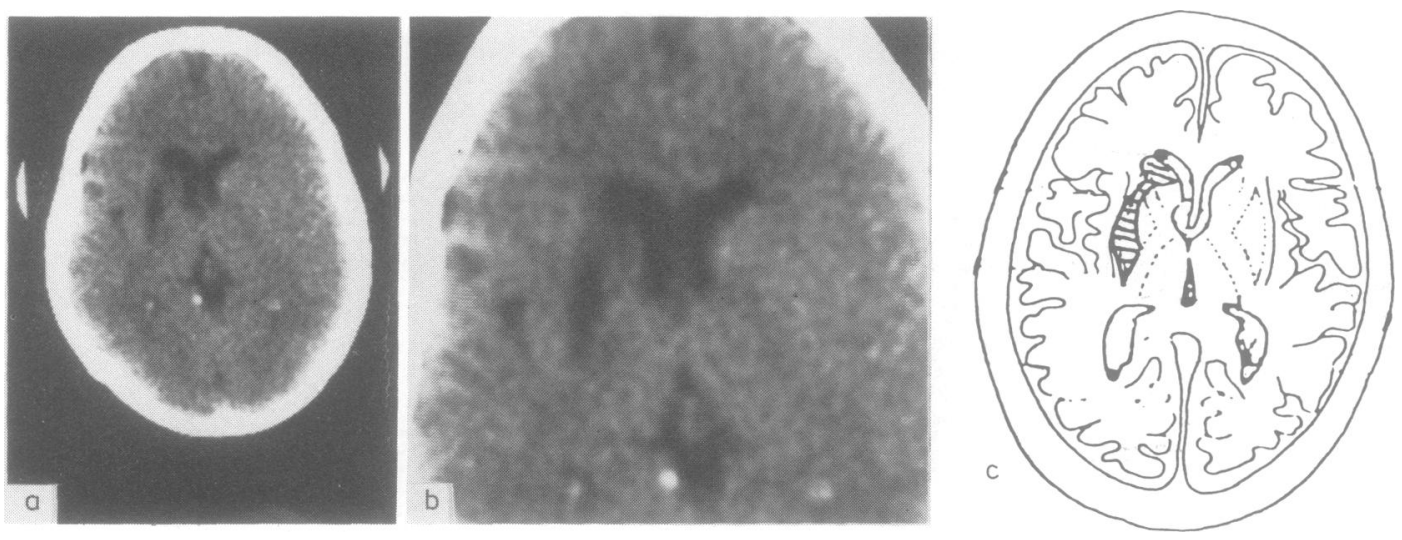

Fig 2 Case 2 CT scan without contrast: hypodensity of the right putamino-capsulo-caudate region.

arrhythmias. Surface electromyography of the left biceps, triceps, extensor and flexor muscles of the wrist revealed continued and very prolonged spontaneous activity of these muscles. This activity was increased by stress and voluntary movements. Furthermore, there was rhythmic activity of these muscles at $10 \mathrm{~Hz}$. Passive mobilisation of the left elbow revealed the existence of a shortening reflex in the biceps and triceps muscles and a tonic myotatic reflex in the triceps. These dystonic alterations were improved by piribedil.

A second CT scan two years after the initial crisis showed a hypodensity of the right lenticulo-capsulo caudate region (fig 3 ).

\section{Discussion}

The putamino-capsulo-caudate lesions observed in the three preceding cases were due to ischaemia in the territory of the lenticulo-striate artery near its origin from the middle cerebral artery, before penetrating the anterior perforated substance. According to Salamon et $a l^{16}$ and to Percheron, ${ }^{17}$ approximately 20 arterioles detach themselves from the middle cerebral artery and divide into two groups: the internal pedicle-giving the lenticular arteries-and the external pedicle-giving the lenticulo-striate arteries. These irrigate the putamen, the external pallidum, the anterior limb of the internal capsule, to terminate in the body and posterior part of the head of the caudate nucleus. ${ }^{17-19}$ After experimental occlusion, the extent of the ischaemic zone depends on lepto-meningeal anastomosis or on anastomosis between internal or external lenticulo-striate arteries. ${ }^{19}$

The lesions causing contralateral limb dystonia were confined to a relatively limited region. In the 19 cases of unilateral dystonia, assembled in tables 1 (anatomical confirmation of site of lesion) and 2 (neuroradiologically suggested site of lesion), the caudate nucleus and putamen were involved 13 times. In these cases, the lesions extended to the anterior limb of the internal capsule, with exception of cases no 1 and no 2, but the latter lacked exact
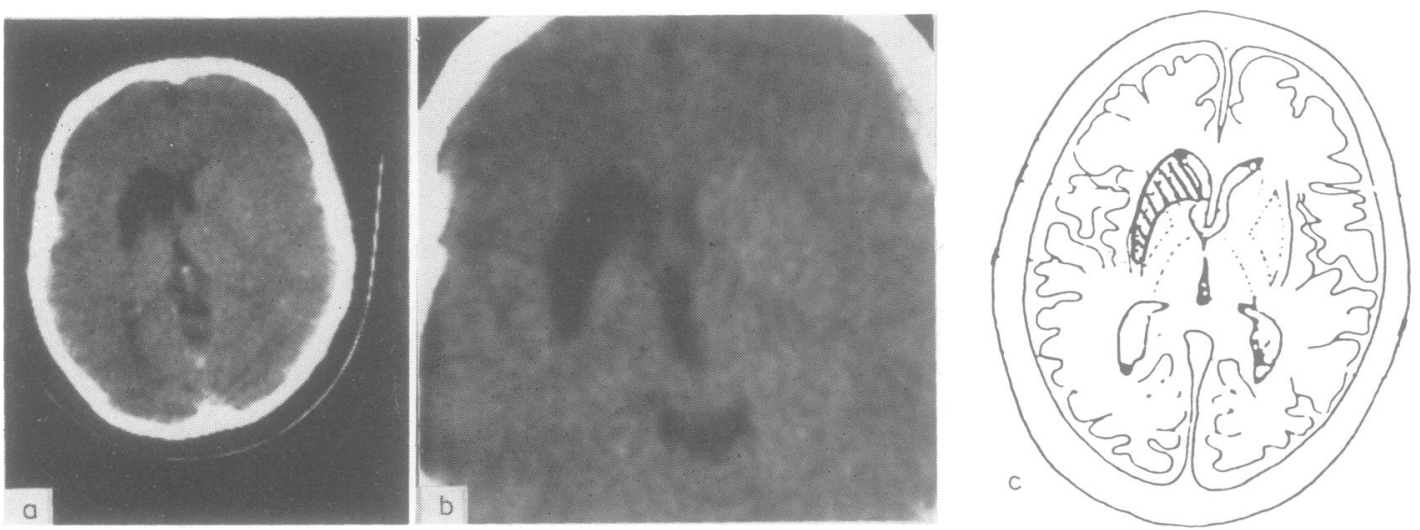

Fig 3 Case 3 CT scan without contrast: hypodensity of the right putamino-capsulo-caudate region. 
Table 1 Unilateral dystonia with anatomical verification of site of lesion

\begin{tabular}{|c|c|c|c|c|c|c|c|}
\hline Authors & $\operatorname{Sex}$ & $\begin{array}{l}\text { Age at onset } \\
\text { of initial } \\
\text { disease } \\
(y r)\end{array}$ & $\begin{array}{l}\text { Most probable } \\
\text { aetiology }\end{array}$ & $\begin{array}{l}\text { Initial } \\
\text { neurological } \\
\text { deficit }\end{array}$ & $\begin{array}{l}\text { Interval of } \\
\text { onset of } \\
\text { dystonia }\end{array}$ & $\begin{array}{l}\text { Type of extra- } \\
\text { pyramidal signs }\end{array}$ & Site of lesion \\
\hline $\begin{array}{l}\text { 1-Austregesilo, } \\
\text { Borges-Forte }^{24}\end{array}$ & $\mathbf{F}$ & 68 & stroke & $\begin{array}{l}\text { hypotonia } \\
\text { demential state } \\
\text { Mutism? }\end{array}$ & immediate & $\begin{array}{l}\text { torsion spasms } \\
\text { with choreiform } \\
\text { movements }\end{array}$ & $\begin{array}{l}\text { head } \mathrm{CN} \\
\text { Put } \\
\text { Pall }\end{array}$ \\
\hline 2-Denny-Brown ${ }^{1}$ & $\mathbf{M}$ & 6 & epileptic fit & $\begin{array}{l}\text { R. post-ictal } \\
\text { hemiplegia } \\
\text { dysarthria }\end{array}$ & $9 \mathrm{yr}$ & $\begin{array}{l}\text { dystonia of } \\
\text { trunk rUL, rLL }\end{array}$ & $\begin{array}{l}\text { CN } \\
\text { Put } \\
\text { Thal }\end{array}$ \\
\hline 3-Oppenheimer ${ }^{9}$ & $\mathbf{F}$ & 8 & angioma & $\begin{array}{l}\text { sudden loss of } \\
\text { consciousness } \\
\text { l. hemiparesis }\end{array}$ & $?$ & $\begin{array}{l}\text { 1UL dystonia } \\
\text { with "repetitive } \\
\text { spasms" }\end{array}$ & $\begin{array}{l}\text { CN } \\
\text { Put } \\
\text { Ext Cap } \\
\text { Ant L, Int Cap } \\
\text { Pall } \\
\text { Amygd N } \\
\text { Thal }\end{array}$ \\
\hline 4-Dooling, Adams ${ }^{10}$ & $\mathbf{M}$ & 2 & $\begin{array}{l}\text { syphilis } \\
\text { (arteritis) }\end{array}$ & $\begin{array}{l}\text { sudden } \mathbf{r} \\
\text { hemiparesis }\end{array}$ & $10 \mathrm{yr}$ & $\begin{array}{l}\text { rUL, rLL } \\
\text { dystonia with } \\
\text { athetoid } \\
\text { movements }\end{array}$ & $\begin{array}{l}\text { head CN } \\
\text { Put } \\
\text { Ant L, Int Cap } \\
\text { Pall } \\
\text { Amygd N } \\
\text { Thal }\end{array}$ \\
\hline 5-Dooling, Adams ${ }^{10}$ & $\mathbf{M}$ & 6 & fever & $\begin{array}{l}\text { r hemiplegia } \\
\text { and aphasia } \\
\text { ( } 24 \mathrm{~h} \text { onset) } \\
\text { followed by } \\
\text { epileptic fit }\end{array}$ & $14 y$ & $\begin{array}{l}\text { rUL, rLL } \\
\text { dystonia with } \\
\text { "involuntary } \\
\text { spasms" }\end{array}$ & $\begin{array}{l}\text { head CN } \\
\text { Put } \\
\text { Ant and Post L } \\
\text { of Int Cap } \\
\text { Ext Pall } \\
\text { Thal }\end{array}$ \\
\hline 6-Dooling, Adams ${ }^{10}$ & $\mathbf{M}$ & 5 & $\begin{array}{l}\text { fever with } \\
\text { convulsions }\end{array}$ & $\begin{array}{l}\text { post-ictal } \\
\text { aphasia and } \\
\text { r. hemiplegia }\end{array}$ & several months & $\begin{array}{l}\text { dystonia of } \\
\text { trunk rUL and } \\
\text { rLL with } \\
\text { athetoid } \\
\text { movements }\end{array}$ & $\begin{array}{l}\text { head CN } \\
\text { Put } \\
\text { Ant and Post L } \\
\text { of Int Cap } \\
\text { Ext Pall } \\
\text { Thal }\end{array}$ \\
\hline 7-Dooling, Adams ${ }^{10}$ & $\mathbf{M}$ & 2 & $\begin{array}{l}\text { scarlet fever } \\
\text { syphilis }\end{array}$ & hypotonia & $?$ & $\begin{array}{l}\text { rUL, rLL } \\
\text { dystonia }\end{array}$ & $\begin{array}{l}\text { head CN } \\
\text { Put } \\
\text { Ant and Post L } \\
\text { of Int Cap } \\
\text { Thal }\end{array}$ \\
\hline 8-Dooling, Adams ${ }^{10}$ & $\mathbf{F}$ & 3 & convulsive crisis & $\begin{array}{l}\text { post-ictal } \\
\text { 1. hemiplegia }\end{array}$ & $16 \mathrm{yr}$ & $\begin{array}{l}\text { 1UL, 1LL } \\
\text { dystonia with } \\
\text { athetoid } \\
\text { movements }\end{array}$ & $\begin{array}{l}\text { CN } \\
\text { Put, Thal } \\
\text { Ant and Post L } \\
\text { of Int Cap }\end{array}$ \\
\hline
\end{tabular}

$\mathbf{r}=$ right, $1=$ left, $\mathrm{UL}=$ upper limb, $\mathrm{LL}=$ lower limb, $\mathrm{L}=\operatorname{limb}, \mathrm{CN}=$ caudate nucleus, Put $=$ putamen, Pall $=$ pallidum, Thal = thalamus, Ant $=$ anterior, Int cap $=$ internal capsule, Post $=$ posterior, Ext $=$ external, $\mathbf{A m y g d}=$ amygdaloid, $\mathbf{M}=$ male, $F=$ female

information. In the majority of observations (14 out of 19) the lesions occurred before 10 years of age, often quite early in childhood. This is common in athetosis. A hemiplegia usually precedes the occurrence of the dystonia (14 cases), and was present in our three cases. Dystonia developed either immediately following the hemiplegia (cases no 9, 14, 17, 18,19 ) or much later (cases no $2,4,5,8,11,12$, 13).

The ischaemia occurring in young individuals can be attributed either to head injury ( 7 cases) particularly children under 10 years of age, to vascular malformations (cases no 3,17 ) or to embolism (case no 19). An initial temperature rise led certain authors to suspect an arteritic cause (cases no 4,7 ).

The mechanism responsible for elective involvement of lenticulo-striate arteries following head injury, has been suggested by Maki $e a{ }^{20}$ as being a torsion of the pedicle. Oppenheimer ${ }^{9}$ believed that vascular malformations could cause ischaemia through spasm, even in the absence of a proven haemorrhage. The predominance of anoxic lesions in this zone is accounted for by the particular sensitivity of these structures to anoxia. ${ }^{20}$.

The three preceding cases and other similar ones reported by the literature, make it possible to suggest that lesions of caudate nucleus, putamen and anterior limb of internal capsule may induce dystonia. This most often is the case if the lesion occurs during childhood. Indeed of 11 cases of capsular infarct in hypertensive patients reported by Fisher, ${ }^{22}$ even though seven cases where located in the putamen and anterior limb of the internal capsule, not one developed dystonia, whether or not the caudate 
Table 2 Unilateral dystonia with site of lesion based on CT scan image except case no 9 (pneumoencephalography) and case no 11 (no neuroradiological examination).

\begin{tabular}{|c|c|c|c|c|c|c|c|}
\hline Authors & $\operatorname{Sex}$ & $\begin{array}{l}\text { Age at onset } \\
\text { of initial } \\
\text { disease } \\
\text { (yr) }\end{array}$ & $\begin{array}{l}\text { Most probable } \\
\text { aetiology }\end{array}$ & $\begin{array}{l}\text { Initial } \\
\text { neurological } \\
\text { deficit }\end{array}$ & $\begin{array}{l}\text { Interval of } \\
\text { onset of } \\
\text { dystonia }\end{array}$ & $\begin{array}{l}\text { Type of extra- } \\
\text { pyramidal signs }\end{array}$ & Site of lesion \\
\hline $9-O^{\prime}$ Callaghan ${ }^{8}$ & $\mathbf{F}$ & 10 & head injury & $\begin{array}{l}\text { 1. hemiplegia } \\
\text { (several hours } \\
\text { later) }\end{array}$ & 4 weeks & $\begin{array}{l}\text { torsion dystonia } \\
\text { "with spasms" }\end{array}$ & $?$ \\
\hline 10-Messimy et al. ${ }^{11}$ & $\mathbf{M}$ & 21 & head injury & none & $4 \mathrm{yr}$ & $\begin{array}{l}\text { torsion dystonia } \\
\text { lUL with } \\
\text { choeiform } \\
\text { movements }\end{array}$ & r head $\mathbf{C N}$ \\
\hline 11-Burke et al. ${ }^{12}$ & $\mathbf{F}$ & 2 & head injury & $\begin{array}{l}\text { r. hemiparesis } \\
\text { aphasia }\end{array}$ & $6 \mathrm{yr}$ & $\begin{array}{l}\text { rUL and rLL } \\
\text { dystonia with } \\
\text { athetoid } \\
\text { movements }\end{array}$ & $?$ \\
\hline 12-Burke et al. ${ }^{12}$ & $\mathbf{F}$ & 65 & stroke & $\begin{array}{l}\text { sudden } 1 . \\
\text { hemiparesis }\end{array}$ & $1 \mathrm{yr}$ & $\begin{array}{l}\text { IUL and ILL } \\
\text { dystonia }\end{array}$ & $\begin{array}{l}\text { r. middle cerebral } \\
\text { artery territory }\end{array}$ \\
\hline 13-Burke et al. ${ }^{12}$ & $\mathbf{M}$ & 54 & stroke & 1. hemiparesis & $1 \mathrm{yr}$ & $\begin{array}{l}\text { IULL and ILL } \\
\text { dystonia }\end{array}$ & no visible lesion \\
\hline 14-Maki et al. ${ }^{20}$ & $\mathbf{F}$ & 5 & $\begin{array}{l}\text { head injury } \\
\text { followed by } \\
\text { epileptic fit }\end{array}$ & 1. hemiparesis & $\begin{array}{l}6 \mathrm{~h} \\
3 \text { days }\end{array}$ & $\begin{array}{l}\text { 1. athetoid } \\
\text { movements } \\
\text { spasmodic } \\
\text { torticollis }\end{array}$ & $\begin{array}{l}\text { CN } \\
\text { Put. } \\
\text { Ant } L \\
\text { of Int. Cap. }\end{array}$ \\
\hline 15-Brett et al. ${ }^{14}$ & $\mathbf{M}$ & 5 & head injury & none & 1 week & $\begin{array}{l}\text { IUL and lLL } \\
\text { dystonia with } \\
\text { athetoid } \\
\text { movements }\end{array}$ & $\begin{array}{l}\text { Put } \\
\text { Post L of } \\
\text { Int Cap }\end{array}$ \\
\hline 16-Andrews et al. ${ }^{15}$ & $\mathbf{M}$ & 8 & head injury & none & $24 \mathrm{~h}$ & $\begin{array}{l}\text { lUL torsion } \\
\text { dystonia, l. oro- } \\
\text { facial dystonia, } \\
\text { lUL hemiballic } \\
\text { and lLL } \\
\text { myoclonic } \\
\text { movements }\end{array}$ & $\begin{array}{l}\text { head CN } \\
\text { lentiform } n \\
\text { Ant. L of } \\
\text { Int Cap }\end{array}$ \\
\hline $\begin{array}{l}17 \text {-Personal case } \\
\text { (Case 1) }\end{array}$ & $\mathbf{F}$ & 3 & $\begin{array}{l}\text { head injury } \\
\text { Angioma? }\end{array}$ & $\begin{array}{l}\text { r. hemiparesis } \\
\text { dysarthria } \\
\text { ( } 48 \text { hours later) }\end{array}$ & 1 mon & $\begin{array}{l}\text { rUL and rLL } \\
\text { dystonia with } \\
\text { choreo-athetoid } \\
\text { movements }\end{array}$ & $\begin{array}{l}\text { head CN } \\
\text { Put } \\
\text { Ant L of } \\
\text { Int Cap } \\
\text { Ext Pall }\end{array}$ \\
\hline $\begin{array}{l}\text { 18-Personal case } \\
\text { (Case 2) }\end{array}$ & $\mathbf{F}$ & 6 & $\begin{array}{l}\text { discomfort with } \\
\text { loss of } \\
\text { consciousness }\end{array}$ & $\begin{array}{l}\text { sudden } \\
\text { l. hemiplegia }\end{array}$ & 1 mon & $\begin{array}{l}\text { postural tremor } \\
\text { IUL and ILL } \\
\text { dystonia with } \\
\text { choreo-athetoid } \\
\text { movements }\end{array}$ & $\begin{array}{l}\text { head CN } \\
\text { Put } \\
\text { Ant } L \text { of } \\
\text { Int Cap } \\
\text { Ext Pall }\end{array}$ \\
\hline $\begin{array}{l}\text { 19-Personal case } \\
\text { (Case 3) }\end{array}$ & $\mathbf{M}$ & 17 & embolic stroke & $\begin{array}{l}\text { sudden } \\
\text { 1. hemiplegia }\end{array}$ & 1 mon & $\begin{array}{l}\text { IUL and ILL } \\
\text { dystonia with } \\
\text { athetoid } \\
\text { movements }\end{array}$ & $\begin{array}{l}\text { head CN } \\
\text { Put } \\
\text { Ant } L \text { of } \\
\text { Int Cap } \\
\text { Ext Pall }\end{array}$ \\
\hline
\end{tabular}

nucleus was involved. Likewise, no dystonic syndrome occurred in 11 patients over 50 years of age reported by Damasio et al, ${ }^{23}$ with ischaemic lesions in the same territory. It is extremely rare for dystonia to occur when such a lesion develops in adults. ${ }^{1224}$

We thank the following for their invaluable contributions: Professor D Fredy, neuroradiogist, Dr N Bathien electromyographist, Dr K Strommer for the translation of this text.

\section{References}

'Denny-Brown D. The basal ganglia. London: Oxford University, 1962
${ }^{2}$ Zeman W, Dyken P. Dystonia musculorum deformans. In: Vinken PJ, Bruyn GW, eds. Handbook of Clinical Neurology. Amsterdam: North-Holland, vol 6:51743.

${ }^{3}$ Eldridge R. The torsion dystonias: literature review, genetic and clinical studies. Neurology (Minneap) 1970;20:1-78.

${ }^{4}$ Bargeton-Farkas E, Cochard AM, Brissaud HE, Robain $\mathrm{O}$, Le Balle JC. Encéphalopathie infantile familiale avec nécrose bilatérale et symétrique des corps striés. J Neurol Sci 1964;1:429-45.

${ }^{5}$ Vogt C. Quelques considérations générales à propos du syndrome du corps strié. J Psycho Neurol (Leipzig) 1911;18:479-88.

${ }^{6}$ Chorobski J. Involuntary movements in patients with intracranial tumours. Arch Neurol 1962;6:27-56.

${ }^{7}$ Hawke WM, Donohue M. Bilateral symetrical necrosis 
of the corpora striata. Report of a fatal case with reference to a possible syndrome of the corpora striata. J Nerv Ment Dis 1951;113:20-39.

${ }^{8}$ O'Callaghan ED. Torsion dystonia complicating childhood hemiplegia. Med J Aust 1962;49:465-68.

${ }^{9}$ Oppenheimer DR. A case of striatal hemiplegia. $J$ Neurol Neurosurg Psychiatry 1967;30:134-9.

${ }^{10}$ Dooling EC, Adams RD. The pathological anatomy of post-hemiplegic athetosis. Brain 1975;98:29-48.

"Messimy R, Diebler C, Metzger J. Dystonie de torsion du membre supérieur gauche, probablement consécutive à un traumatisme crânien. Rev Neurol (Paris) 1977;133,3:199-206.

12 Burke RE, Fahn S, Gold AP. Delayed-onset dystonia in patients with "static" encephalopathy. J Neurol Neurosurg Psychiatry 1980;43:789-97.

${ }^{13}$ Rondot P. Les ganglions de la base. Approche clinique et physiopathologique. $J$ Physiol (Paris) 1981;77:119-30.

${ }^{14}$ Brett EM, Hoare RD, Sheehy MP, Marsden CD. Progressive hemidystonia due to focal basal ganglia lesion after mild head trauma. J Neurol Neurosurg Psychiatry 1981; 44:460.

15 Andrew J, Fowler C, Harrison MJG. Hemi-dystonia due to focal basal ganglia lesion after head injury and improved by stereotaxic thalamotomy. J Neurol Neurosurg Psychiatry 1982;45:276.
${ }^{16}$ Salamon G, Boudouresque J, Combalbert A, Khalil R, Faure J, Giudicelli G. Les artéres lenticulo-striées. Etude arterio-graphique. Rev Neurol (Paris) 1966;114,5:361-73.

${ }^{17}$ Percheron G. Arterial supply of the thalamus. In: Schaltenbrand G, Walker AE, eds. Stereotaxy of the Human Brain, Stuttgart: Georg Thieme Verlag, 1982:218-32.

${ }^{18}$ Lazorthes G. Vascularisation et circulation cérébrale. Paris: Masson, 1956.

${ }^{19}$ Yonas H, Wolfson SK, Dujovny M, Boehnke M, Cook E. Selective lenticulostriate occlusion in the primate. Stroke 1981;12,5:567-72.

${ }^{20}$ Maki Y, Akimoto H, Enomoto T. Injuries of basal ganglia following trauma in children. Childs Brain 1980;7:113-23.

${ }^{21}$ Poirier F, Miribel J, Fournet A, Garde A. Un cas de comitialité avec hémiparésie et mouvements anormaux. Journal de Medicine de Lyon 1961:1357-66.

${ }^{22}$ Fisher CM. Capsular infarcts. The underlying vascular lesions. Arch Neurol 1979;36:65-73.

${ }^{23}$ Damasio AR, Damasio H, Rizzo M, Varney N, Gersh F. Aphasia with nonhemorrhagic lesions in the basal ganglia and internal capsule. Arch Neurol 1982;39:15-20.

${ }^{24}$ Austregesilo A, Borges-Forte A. Sur un cas d'hémichorée avec lésion du noyau caudé. Rev Neurol (Paris) 1937;67,4:477-88. 